\title{
The relationship between Gamma- Glutamyltransferase activity and atrial fibrillation In patients with reduced ejection fraction heart failure
}

\section{Azalmış ejeksiyon fraksiyonu kalp yetersizliğinde Gama-Glutamiltransferaz aktivitesi ve atriyal fibrilasyon arasındaki ilişki}

\author{
Gulacan Tekin¹, Yusuf Kenan Tekin²
}

${ }^{1}$ Sivas Cumhuriyet University Faculty of Medicine Department of Cardiology, Sivas, Turkey
${ }^{2}$ Sivas Cumhuriyet University Faculty of Medicine, Emergency Department, Sivas, Turkey
Corresponding author: Gulacan Tekin, MD, Sivas Cumhuriyet University Faculty of Medicine Department of Cardiology, Sivas, Turkey
E-mail: gulacantekin@ hotmail.com
Received/Accepted: May 30, 2019 /June 24, 2019
Conflict of interest: There is not a conflict of interest.

\section{SUMMARY}

Objective: Clinically, gamma-glutamyltransferase (GGT) activity is generally used as a diagnostic test for liver function, biliary tract pathologies, and alcohol consumption. GGT is the enzyme that manages the extracellular catabolism of the main antioxidant glutathione, thus increasing the oxidative stress or inflammatory state. Recently studies reported that GGT is related to cardiovascular mortality and morbidity independently alcohol consumption. Elevation of GGT in heart failure (HF), atrial fibrillation (AF), coronary artery disease, myocardial infarction, and metabolic syndrome is explained with inflammation and oxidative stress. Aim of this study, we have examined the relation between GGT and AF in reduced ejection fraction heart failure (HFrEF) patients group.

Method: Totally one hundred and sixty-three ischemic HF patients were included in the study retrospectively. Electrocardiographically 63 patients have $\mathrm{AF}$ (40 male, 23 females, mean age: $73 \pm 8$ years) and 100 patients have normal sinus rhythm (75 male, 25 female, mean age: $71 \pm 7$ years). All patients had the echocardiographic examination, ejection fraction (EF) $>40 \%$, severe valvular heart disease, and nonischemic HF patients were excluded.

Results: Presence of hypertension, age, gender, dislipidemia history, diabetes, smoking condition, fasting glucose, and cholesterol levels were compared between two groups, and there were not statistically different ( $>0.05$ for all). However, serum GGT activity was increased in patients group with AF compared to those without AF (35(10-121) U/L versus 27(6$113) \mathrm{U} / \mathrm{L}, \mathrm{p}=0.01)$. The optimal cut-off GGT activity for AF patients were $>23,5 \mathrm{IU} / 1$ with a sensitivity of $81 \%$ and a specificity of $46 \%$ (AUC $=0.660$, $95 \% \mathrm{CI}=0.575-0.744)$

Conclusions: In this study, serum GGT activity was concluded to be increased in HFrEF patients with AF compared to without AF group. More comprehensive studies should be planned to improve the clinical use of GGT in patients with HFrEF and to investigate the relationship between GGT and AF.Keywords: Gamma-glutamyltransferase, atrial fibrillation, heart failure, inflammation
Gulacan Tekin

Yusuf Kenan Tekin

ORCID IDs of the authors: G.T. 0000-0002-1355-9298 Y.K.T. 0000-0001-8047-4836 


\section{ÖZET}

Amaç: Klinik olarak, gamma-glutamiltransferaz (GGT) aktivitesi, genellikle karaciğer fonksiyonu, safra yolu patolojileri ve alkol tüketimi için tanısal bir test olarak kullanılır. GGT, oksidatif stres veya enflamatuar durumlarda artan ve önemli bir antioksidan glutatyonun hücre dışı katabolizmasında görev alan bir enzimdir. Son zamanlarda yapılan çalıșmalar GGT'nin alkol tüketiminden bağımsız olarak kardiyovasküler mortalite ve morbidite ile ilgili olduğunu göstermiştir. GGT'nin kalp yetersizliğinde (KY), atriyal fibrilasyonda (AF), koroner arter hastalığında, miyokard enfarktüsünde ve metabolik sendromda yükselmesi, enflamasyon ve oksidatif stres ile açıklanmaktadır. Bu çalışmanın amacı, düşük ejeksiyon fraksiyonlu kalp yetersizliği (DEFKY) hastalarında GGT ile AF arasındaki ilişkiyi araștırmaktır.

Yöntem: Calıșmaya retrospektif olarak toplam yüz altmıș üc iskemik KY hastası dahil edildi. Elektrokardiyografik olarak 63 hastada AF (40 erkek, 23 kadın, ortalama yaş: $73 \pm 8$ yil) ve 100 hastada normal sinüs ritmi (75 erkek, 25 kadın, ortalama yaş: $71 \pm 7$ yıl) vardı. Tüm hastalarda ekokardiyografik inceleme yapıldı, ejeksiyon fraksiyonu (EF) $>\%$ 40, ciddi kalp kapak hastalığı ve iskemik olmayan KY hastaları dışlandı.

Bulgular: Hipertansiyon, yaş, cinsiyet, dislipidemi, diyabet, sigara, açlık glukozu ve kolesterol düzeyleri iki grup arasında karşılaştırıldı ve istatistiksel olarak farklı değildi (hepsi için $\mathrm{p}>0.05$ ). Ancak, AF'li hasta grubunda serum GGT aktivitesi AF olmayanlara göre artmış olduğu görüldü (35 (10-121) U / L, 27 (6-113) U / L, p = 0.01). AF hastaları için en uygun kesme GGT aktivitesi \% 81 duyarlılık ve \% 46 özgüllük ile $>23,5$ IU / 1 idi (AUC $=0.660, \% 95$ CI $=0.575$ $0.744)$.

Sonuç: Bu çalışmada serum GGT aktivitesinin, AF'li DEFKY hastalarında AF olmayan gruba kıyasla artmış olduğu sonucuna varıldı. DEFKY olan hastalarda GGT'nin klinik kullanımı ve GGT ile AF arasındaki ilişkiyi araştırmak için daha kapsamlı çalışmalar planlanmalıdır.

Anahtar sözcükler: Gama-glutamiltransferaz, atriyal fibrilasyon, kalp yetersizliği, inflamasyon

\section{INTRODUCTION}

Chronic heart failure (HF) is a prevalent cause of mortality and morbidity, especially in developed countries. Neurohumoral activation, systemic inflammation, and oxidative stress are an important cornerstone of $\mathrm{HF}$ pathogenesis ${ }^{1}$. Atrial fibrillation (AF), the prevalence of approximately $3 \%$ in adults, is one of the most common cardiac arrhythmias, especially in HF patients, and its incidence increases with age ${ }^{2}$.

Gamma-glutamyltransferase (GGT) is normally found in the membranes of all cells except erythrocytes, in the serum and therefore in the plasma. An important antioxidant in mammals, glutathione is involved in extracellular catabolism. Serum GGT activity is elevated when inflammation and oxidative stress are elevated due to its role in antioxidative reactions. The elevation is parallel to increased of acute phase reactors. GGT activity has been associated with arterial hypertension, diabetes, metabolic syndrome, systemic inflammation, oxidative stress, embolic disease, stroke, arrhythmia, and cardiac death known as traditional cardiovascular risk factors and condition ${ }^{3}$. Serum GGT activity can be reversed with antioxidant vitamin and elevated with dietary heme iron ${ }^{4}$. Elevated GGT levels were associated with an increased risk of AF, especially in nonobese patients in a prospective large population-based study ${ }^{5}$. Increased GGT levels were associated with HF severity, and it was an independent predictor of heart transplantation and death ${ }^{1}$. Since inflammation and oxidative stress increase in both $\mathrm{HF}$ and $\mathrm{AF}$, it is thought that inflammation and oxidative stress can be increased and GGT will be higher in AF patients with HF.

Our study aimed to examine whether serum GGT activity is an indicator of inflammation and oxidative stress in HF patients with and without AF.

\section{MATERIAL AND METHODS}

Patients with ischemic origin HFrEF who admitted our cardiology clinic between January 2016 and April 2018 reviewed retrospectively. A total of 163 patients with heart failure clinic defined as the New York Heart Association (NYHA) Functional Class I-IV patients with an ejection fraction $(\mathrm{EF})$ of $<40 \%$ were analyzed in the study. The study was approved by the local Ethics Committee for Human Research.

Patients demographic, clinical, medical data, and laboratory test results were obtained from the hospital database based on the records. The clinical and demographic parameters of the patients were collected as follows: age, gender, hypertension, diabetes mellitus, hyperlipidemia, and smoking. The presence of hypertension was accepted as patients using antihypertensive drugs or measuring at least two measures of blood pressure 140/90 $\mathrm{mmHg}$ and above. Patients with diabetes mellitus, known diabetes mellitus (patients using antidiabetic drugs), patients whose blood sugar was controlled by dieting, or patients whose blood sugar was $126 \mathrm{mg} / \mathrm{dl}$ after an eight- 
hour fasting. Known hypercholesterolemia, treated with antihyperlipidemic drug or fasting or nonfasting serum cholesterol concentrations higher than $200 \mathrm{mg} / \mathrm{dL}$ were defined as hypercholesterolemia.

Clinical history of coronary heart disease (CAD), pathologic Q waves on electrocardiogram, ischemia evidence in the treadmill stress test, shown segmental left ventricular dyskinesia or akinesia on echocardiogram, or luminal narrowing of any epicardial coronary arteries $>50 \%$ on a coronary angiogram whom coronary angiography was performed previously was defined as coronary heart disease. Smoking is still considered to be smokers who are currently smoking or who have quit within the past year.

Patients with EF $\geq 40 \%$ on echocardiography, nonischemic HF, acute coronary syndrome, acute heart failure, valvular heart disease (moderate-tosevere), presence of pacemaker, hepatic or renal failure ( $>2$-fold of normal serum alanine aminotransferase and aspartate aminotransferase levels; >1.5 mg/dL serum level of creatinine), hypothyroidism or hyperthyroidism, presence of acute or chronic infection, malignancy, connective tissue disease, stroke history, alcohol use, hematological, respiratory, immunological, inflammatory disorders were excluded from the study.

The blood samples were drawn under appropriate conditions after 8 hours of fasting. Beckman Coulter Synchron LX20 (Brea, CA, USA) autoanalyzer and its original kits were used to measure GGT activity and other biochemical tests.

The transthoracic echocardiographic evaluation was done with the Vivid seven cardiac ultrasonography system (GE Healthcare, Medical Systems) by experienced echocardiographers, with $2.5-$ to $5-\mathrm{MHz}$ probes. The modified Simpson method was used to calculate the left ventricular ejection fraction (LVEF) and chamber sizes according to recent guidelines ${ }^{6}$.

Statistical analysis was performed using the SPSS 16.0 packet computer program (SPSS Inc.Chicago, IL, USA), and the value of $\mathrm{P}<0.05$ was approved statistically significant. The Kolmogorov-Smirnov test was used to confirm the normality of the distribution of continuous variables. Continuous variables were expressed as the mean \pm standard deviation in the presence of normal distribution and median (min-max) in the presence of skewed distribution, and categorical variables as percentages. Comparisons between groups for categorical variables, the chi-square or Fisher's exact test were used. Continuous variables were compared using the independent samples t-test for normally distributed variables and Mann-Whitney U test for skewed distributed variables. Receiver operator characteristic (ROC) curve analysis was performed to identify the optimal cut-off point of GGT(at which sensitivity and specificity would be maximum) for the prediction of AF. The area under the curve (AUC) with $95 \%$ confidence interval was estimated in the prediction of AF. The optimal cut-off value of GGT was identified as the value parallel with the highest sum of sensitivity and specificity- 1 .

\section{RESULTS}

A total of $163 \mathrm{HF}$ patients were included in the study and compared, 63 patients were AF (23 women, 40 men, mean age $73 \pm$ eight years) and 100 patients ( 25 women, 75 men, mean age $71 \pm$ seven years) $(\mathrm{p}=0.36)$ were normal sinus rhythm. The demographic characteristics, biochemical, and echocardiographic values of the patients are shown in Table 1. There was no statistically significant difference between the two groups in terms of age, gender, hypertension, the presence of diabetes mellitus, and smoking status ( $p>0.05$ ). There was no statistically significant difference between groups in terms of biochemical tests, including glucose, total cholesterol, triglyceride, HDL-cholesterol, LDL-cholesterol, aspartate aminotransferase, and alanine aminotransferase (p> 0.05). In the AF group, the elevation of serum GGT values was statistically significant (35(10121)U/L vs. 27(6-113) U/L, p = 0.01). There was no statistically significant difference between groups in terms of ejection fractions $(\mathrm{p}=0.16)$ but left atrial diameter (LA) (43 \pm 6 vs. $38 \pm 5, p$ $<0.001)$ and left ventricular end-diastolic diameter (LVEDD) $\quad(56 \pm 7 \quad$ vs. $52 \pm 6, \quad \mathrm{p}=0.001) \quad$ were significantly higher in the $\mathrm{AF}$ group. In the Receiver operating characteristic analysis, the optimal cut-off GGT activity in patients with AF was $>23.5 \mathrm{IU} / 1$ with a sensitivity of $81 \%$ and a specificity of $46 \%$ (AUC $=0.660,95 \%$ CI $=0.575$ $0.744, \mathrm{p}=0.001$ )(Figure 1.). 
Table1: Baseline characteristics of the patients.

\begin{tabular}{|c|c|c|c|}
\hline Variables & $\begin{array}{l}\text { Patients With Normal } \\
\text { Sinus Rhythm (n:100) }\end{array}$ & $\begin{array}{l}\text { Patients With Atrial } \\
\text { Fibrillation (n:63) }\end{array}$ & P Values \\
\hline Mean age (years) & $71 \pm 7$ & $73 \pm 8$ & 0.36 \\
\hline Gender, male, n (\%) & $75(\% 75)$ & $40(\% 64)$ & 0.12 \\
\hline Hypertension, n (\%) & $81(\% 81)$ & $53(\% 84)$ & 0.60 \\
\hline Diabetes mellitus, n (\%) & $20(\% 20)$ & $20(\% 31)$ & 0.15 \\
\hline Hyperlipidemia, n (\%) & $63(\% 63)$ & $46(\% 73)$ & 0.18 \\
\hline Current smoking, n (\%) & $52(\% 52)$ & $33(\% 53)$ & 0.80 \\
\hline White blood cell, $\left(\mathrm{x} \mathrm{10}^{3} / \mu \mathrm{L}\right)$ & $7.4 \pm 1.9$ & $7.7 \pm 1.8$ & 0.34 \\
\hline Hemoglobin $(\mathrm{g} / \mathrm{dl})$ & $14 \pm 1.8$ & $13 \pm 1.3$ & 0.17 \\
\hline Platelet $\left(10^{3} / \mathrm{mL}\right)$ & $219(129-391)$ & $225(108-388)$ & 0.69 \\
\hline Glucose, $(\mathrm{mg} / \mathrm{dL})$ & $101(68-208)$ & $105(71-274)$ & 0.19 \\
\hline $\begin{array}{l}\text { Blood urea nitrogen } \\
(\mathrm{mg} / \mathrm{dL})\end{array}$ & $17(7-40)$ & $19(6-47)$ & 0.64 \\
\hline Creatinine (mg/dl) & $1.01 \pm 0.1$ & $1.01 \pm 0.2$ & 0.84 \\
\hline Total cholesterol (mg/dL) & $158(84-307)$ & 161(86-279) & 0.59 \\
\hline Triglyceride $(\mathrm{mg} / \mathrm{dL})$ & $98(40-248)$ & $84(15-350)$ & 0.44 \\
\hline HDL-cholesterol (mg/dL) & $34(13-62)$ & $33(15-69)$ & 0.12 \\
\hline LDL-cholesterol (mg/dL) & $105(36-215)$ & $107(35-185)$ & 0.79 \\
\hline AST (IU/L) & $21(12-160)$ & $24(13-173)$ & 0.22 \\
\hline ALT (IU/l) & $17(7-71)$ & $19(5-155)$ & 0.30 \\
\hline GGT (IU/l) & $27(6-113)$ & $35(10-121)$ & 0.01 \\
\hline Left ventricle ejection fraction (\%) & $35 \pm 5.9$ & $33 \pm 6.4$ & 0.16 \\
\hline Left atrial diameter, $\mathrm{mm}$ & $3.8 \pm 0.5$ & $4.3 \pm 0.6$ & $<0.001$ \\
\hline LVEDD, mm & $5.2 \pm 0.6$ & $5.6 \pm 0.7$ & 0.001 \\
\hline
\end{tabular}

AST: Aspartate aminotransferase; ALT: Alanine aminotransferase; GGT: Gamma-glutamyl transferase; HDL: Highdensity lipoprotein; LDL: Low-density lipoprotein; LVEDD: Left ventricular end diastolic diameter

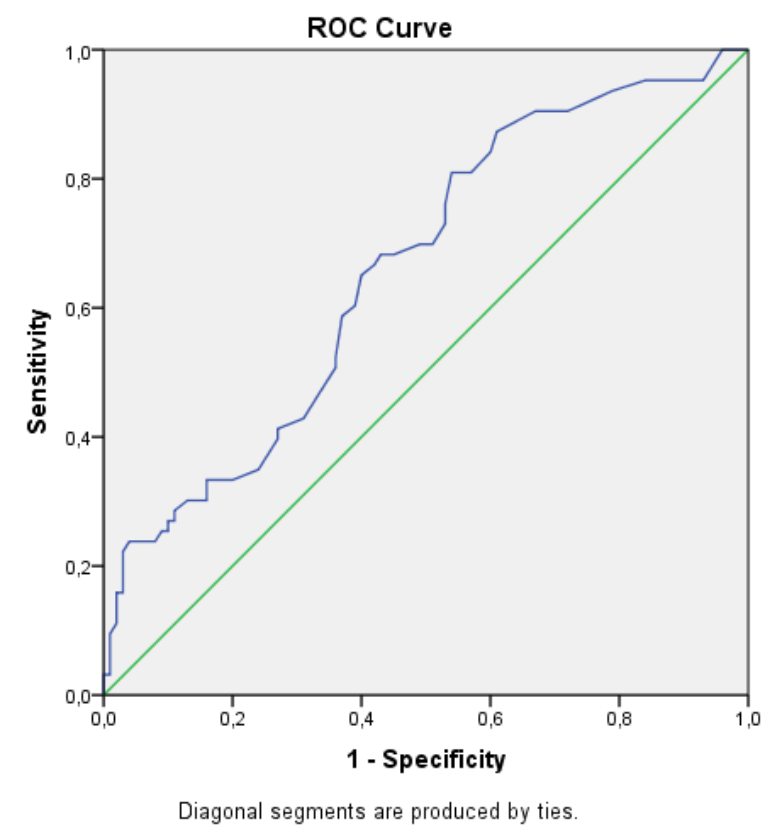

Figure 1: Receiver operating characteristic (ROC) curve for gamma-glutamyl transferase (GGT) activity in patients with AF. 


\section{DISCUSSION}

GGT is an essential enzyme that plays an important role in the metabolism of glutathione, the most important antioxidant produced in humans cell. Serum GGT activity is known to be a marker of oxidative stress ${ }^{3}$. These study findings revealed that GGT was related to AF in HFrEF patients. Previous studies showed that GGT levels were associated with both $\mathrm{HF}^{1}$ and $\mathrm{AF}^{7,8}$ separately. However, serum GGT activity is not well analyzed in AF patients with HFrEF.

In a routine health screening, GGT is a biochemical parameter that is easily accessible, inexpensive, highly sensitive, and clinically diagnostic for hepatic, biliary diseases, and alcohol consumption. Serum GGT activity has also been associated with diet. Dietary components containing plant foods and fruits were negatively associated with serum GGT activity, but meat consumption was positively associated ${ }^{9}$. Aside this classical well knew, the importance of GGT in anti-inflammatory and antioxidant reactions were determined in many studies such as hypertension, diabetes, metabolic syndrome, HF, $\mathrm{AF}$, arrhythmias, stroke, CHD and mortality ${ }^{1,7,10-}$ 14

$\mathrm{HF}$ and $\mathrm{AF}$ comorbidity are common, and one can be the cause or result of the other. The presence of one can trigger the other, and coexistence worsens the prognosis. In both conditions, age, hypertension, valvular disease, myocardial infarction, and genetic causes are common risk factors ${ }^{15}$.

$\mathrm{AF}$ is one of the most common cardiac arrhythmias with increasing prevalence with age and rising to $10 \%$ by the age of 80 years ${ }^{16}$. The inflammatory process plays an important role in the pathogenesis of $\mathrm{AF}^{16,17}$. GGT is known as a marker of oxidative stress, which plays an important role in the defense system ${ }^{15}$. Large, prospective, community-based cohort The Atherosclerosis Risk in Communities (ARIC) study showed that elevated GGT levels associated with $\mathrm{AF}$ incidence even at in the normal range during mean follow-up 12 years $^{7}$. A Korean nationwide population-based study included 266550 patients during a median 8-year follow-up period and reported that 5034 patients (1.9\%) had new AF patients. The elevation of GGT levels was associated with AF, especially in the nonobese population. Furthermore, the intensity elevation of GGT levels was related to the occurrence of AF. However, there was no relationship in the obese population ${ }^{5}$.
GGT levels were found high and associated with disease severity in patients with both ischemic and non-ischemic chronic heart failure. Poelzl et al. followed up 1053 consecutive white patients for mean 34.4 months and evaluated for death from any cause or heart transplantation. The GGT levels were found an independent predictor of death or heart transplantation. Also, high GGT levels were positively associated with increased levels of NT-proBNP, uric acid, and C-reactive protein ${ }^{1}$.

GGT activity was evaluated by the British Regional Heart Study in 7613, middle-aged British men. The patients followed 11.5 years, and serum GGT activity was declared that was associated with cardiovascular risk factors and allcause mortality even within the normal limit $(\text { GGT }>24 \mathrm{U} / \mathrm{L})^{18}$. In the Framingham Heart Study, 3451 patients were followed up for 19 years, and the highest quartile of GGT was detected in $67 \%$ of the increased incidence of CVD. Serum GGT also predicted the onset of metabolic syndrome and death ${ }^{19}$. GGT activity was associated with $\mathrm{CV}$ risk factors and increased $\mathrm{CV}$ mortality in prospectively designed Austrian and Finnish study ${ }^{20,21}$.

Elevation of GGT was associated with the development of hypertension, both diabetic and non-diabetic patients. GGT elevation was significant for systolic blood pressure, but there was no significance for diastolic blood pressure in diabetic patients ${ }^{11}$. Serum GGT activity has been associated with microalbuminuria in diabetic or hypertensive patients, and an effective mechanism is thought to be oxidative mechanisms ${ }^{10}$. Serum GGT activity associated with vascular events and stroke $^{12-14}$. The relationship between GGT activity and risk factors that increase cardiovascular events can be explained by oxidative stress and inflammation ${ }^{4}$.

Increased of GGT was associated with both ischemic and hemorrhagic stroke in the age and sex-adjusted population. The association didn't attenuate even if the adjustment of confounding variables such as drug use, history of myocardial infarction, total cholesterol, and diabetes mellitus ${ }^{13}$. Serum GGT concentration was associated with intracerebral hemorrhage in men, the risk of subarachnoid hemorrhage in women, and increased risk of ischemic stroke in both genders $^{14}$.

Study Limitations: There were some limitations to our study. The study design was retrospective, the number of patients was relatively small, and all of the patients were the single center. That's 
why the results cannot be generalized of all $\mathrm{HF}$ patients. Furthermore, since our study is not prospective, it is not clear whether the increase in GGT levels is the cause or result of $\mathrm{AF}$ development.

GGT activity and its relation on AF in HFrEF patients should be assessed with prospectively designed and long-term follow-up study in the bigger number of participants. In prospective studies, natriuretic peptides, inflammatory markers such as cytokines and interleukins, as well as GGT activity, should be included in the study. Confirmation of AF relationship with GGT activity and its relationship with mortality may provide a significant contribution to the prognosis and survival of HFrEF patients. GGT was found to be elevated in $\mathrm{AF}$ patients with ischemic HFrEF, but further extensive studies are needed to use as routine examinations.

\section{CONCLUSION}

Patients with AF had higher serum GGT activity in patients with HFrEF. But this study does not provide information that elevated GGT levels are cause or outcome of AF.

\section{Declaration of Conflicting Interests}

The authors declared no potential conflicts of interest concerning the research, authorship, and publication of this article.

\section{Funding}

The authors received no financial support for the research, authorship, and publication of this article.

\section{REFERENCES}

1. Poelzl G, Eberl C, Achrainer H, Doerler J, Pachinger O, Frick M, et al. Prevalence and prognostic significance of elevated gamma-glutamyltransferase in chronic heart failure. Circ Heart Fail. 2009 Jul;2(4):294-302.

2. Kirchhof $P$, Benussi $S$, Kotecha D, Ahlsson A, Atar D, Casadei B, et al. 2016 ESC Guidelines for the management of atrial fibrillation developed in collaboration with EACTS. Eur Heart J. 2016 Oct 7;37(38):2893-2962. doi: 10.1093/eurheartj/ehw210.

3. Ndrepepa G, Colleran R, Kastrati A. Gamma-glutamyl transferase and the risk of atherosclerosis and coronary heart disease. Clin Chim
Acta. $2018 \quad$ Jan;476:130-138. doi: 10.1016/j.cca.2017.11.026.

4. Lee DH, Blomhoff R, Jacobs DR Jr. Is serum gamma glutamyltransferase a marker of oxidative stress? Free Radic Res. 2004 Jun;38(6):535-9.

5. Lee SR, Choi EK, Han KD, Cha MJ, Oh S. Association between $\gamma$ glutamyltransferase level and incidence of atrial fibrillation: A nationwide population-based study. Int J Cardiol. 2017 Oct 15;245:149-155. doi: 10.1016/j.ijcard.2017.07.067.

6. Lang RM, Bierig $M$, Devereux RB, Flachskampf FA, Foster E, Pellikka PA, et al, Chamber Quantification Writing Group. Recommendations for chamber quantification. Eur $\mathrm{J}$ Echocardiogr. 2006;7(2): 79-108.

7. Alonso A, Misialek JR, Amiin MA, Hoogeveen RC, Chen LY, Agarwal SK, et al. Circulating levels of liver enzymes and incidence of atrial fibrillation: the atherosclerosis risk in communities cohort. Heart. 2014 Oct;100(19):1511-6. doi: 10.1136/heartjnl-2014-305756.

8. Tekin G, Tekin YK, Amanvermez Senarslan D, Gocmen AY, Senarslan O, Erbay AR. Serum $\gamma$-Glutamyltransferase Activity in Patients With Nonvalvular Atrial Fibrillation. Angiology. 2013 Feb;64(2):157-60. doi: 10.1177/0003319712438956.

9. Lee DH, Steffen LM, Jacobs DR Jr. Association between serum gammaglutamyltransferase and dietary factors: the Coronary Artery Risk Development in Young Adults (CARDIA) Study. Am J Clin Nutr. 2004 Apr;79(4):600-5.

10. Lee DH, Jacobs DR Jr, Gross M, Steffes M. Serum gamma-glutamyltransferase was differently associated with microalbuminuria by status of hypertension or diabetes: the Coronary Artery Risk Development in Young Adults (CARDIA) Study. Clin Chem. 2005 Jul;51(7):1185-1891.

11. Kotani K, Shimohiro H, Adachi S, Sakane $\mathrm{N}$. The association between an increased level of gamma-glutamyl transferase and systolic blood pressure in diabetic subjects. Tohoku J Exp Med. 2008 Apr;214(4):321-5. 
12. Fraser A, Harris R, Sattar N, Ebrahim S, Smith GD, Lawlor DA. Gammaglutamyltransferase is associated with incident vascular events independently of alcohol intake. Analysis of the British Women's Heart and Health Study and meta-analysis. Arterioscler Thromb Vasc Biol 2007; 27: 2729-2735.

13. Bots ML, Salonen JT, Elwood PC, Nikitin Y, Freire de Concalves A, et al. Gammaglutamyltransferase and risk of stroke: the EUROSTROKE project. J Epidemiol Comm Health 2002 Feb;56 Suppl 1:i25-9.

14. Jousilhati P, Rastenyte D, Tuomilehto J. Serum gamma-glutamyl transferase, selfreported alcohol drinking and the risk of stroke. Stroke 2000 Aug;31(8):1851-5.

15. S. Bulusu, M. Sharma, What does serum gamma-glutamyltransferase tell us as a cardiometabolic risk marker? Ann. Clin. Biochem. 53 (2016) 312-332.

16. Ozaydin M. Atrial fibrillation and inflammation. World J Cardiol. 2010 Aug 26;2(8):243-250.

17. Issac TT, Dokainish H, Lakkis NM. Role of inflammation in initiation and perpetuation of atrial fibrillation: a systematic review of the published data. $\mathbf{J}$ Am Coll Cardiol 2007; 50: 2021-2028

18. Wannamethee G, Ebrahim S, Shaper G. Gamma-glutamyltransferase:

determinants and association with mortality from ischaemic heart disease and all causes. Am J Epidemiol 1995; 142: 699-708.
19. Lee DS, Evans JC, Robins SJ, Wilson PW, Albano I, Fox CS, et al. Gamma glutamyl transferase and metabolic syndrome, cardiovascular disease, and mortality risk: the Framingham heart study. Arterioscler Thromb Vasc Biol. 2007 Jan;27(1):127-33.

20. Ruttmann E, Brant LJ, Concin H, Diem G, Rapp K, Ulmer H; Vorarlberg Health Monitoring and Promotion Program Study Group. Gamma-glutamyltransferase as a risk factor for cardiovascular disease mortality: an epidemiological investigation in a cohort of 163,944 Austrian adults. Circulation. 2005 Oct 4;112(14):2130-2137.

21. Lee DH, Silventoinen K, Hu G, Jacobs DR Jr, Jousilahti P, Sundvall J, et al. Serum gamma-glutamyltransferase predicts non-fatal myocardial infarction and fatal coronary heart disease among 28,838 middle-aged men and women. Eur Heart J. 2006 Sep;27(18):2170-2176. 